Article

\title{
Optimized Conversion of Waste Cooking Oil to Biodiesel Using Calcium Methoxide as Catalyst under Homogenizer System Conditions
}

\author{
Ming-Chien Hsiao ${ }^{1,2}$, Shuhn-Shyurng Hou ${ }^{2,3, *}$, Jui-Yang Kuo ${ }^{1}$ and Pei-Hsuan Hsieh ${ }^{4}$ \\ 1 Department of Environmental Engineering, Kun Shan University, Tainan 71070, Taiwan; \\ johnson@mail.ksu.edu.tw (M.-C.H.); dbormana@gmail.com (J.-Y.K.) \\ 2 Green Energy Technology Research Center, Kun Shan University, Tainan 71070, Taiwan \\ 3 Department of Mechanical Engineering, Kun Shan University, Tainan 71070, Taiwan \\ 4 Department of Materials Science and Engineering, National Tsing Hua University, Hsinchu 30013, Taiwan; \\ s105031532@m105.nthu.edu.tw \\ * Correspondence: sshou@mail.ksu.edu.tw; Tel.: +886-6-205-0496
}

Received: 4 September 2018; Accepted: 29 September 2018; Published: 1 October 2018

\begin{abstract}
Although many types of heterogeneous catalysts have been applied to the transesterification reaction, some of them are unsuitable for industrial applications due to their high price and the extra preparation required to synthesize them. Calcium methoxide is a low cost, strong base with high catalytic activity and is thus commonly used in the biofuels synthesis process during the transesterification reaction. The objective of this study was to determine the optimized conversion in the transesterification reaction of waste cooking oil (WCO) for biodiesel production by using a homogenizer with a calcium methoxide catalyst. It was shown that the optimal reaction conditions are a methanol-to-oil molar ratio of $6: 1,4 \mathrm{wt} \% \mathrm{Ca}\left(\mathrm{OCH}_{3}\right)_{2}$, a reaction temperature of $65^{\circ} \mathrm{C}$, a rotation speed of $7000 \mathrm{rpm}$, and a reaction time of $90 \mathrm{~min}$. The conversion rate under these conditions reached $90.2 \%$. $\mathrm{Ca}\left(\mathrm{OCH}_{3}\right)_{2}$ thus has potential as a catalyst for industrial use. In addition, with a homogenizer system, the reaction time for synthesizing calcium methoxide catalyst can be reduced by half compared to that for conventional water-bath heating. In addition, the large amount of waste water required in the oil-water separation step can be reduced by using calcium methoxide instead of a homogeneous catalyst, significantly reducing manufacturing costs.
\end{abstract}

Keywords: biodiesel; transesterification; waste cooking oil; homogenizer; calcium methoxide

\section{Introduction}

Biodiesel, also called fatty acid methyl esters (FAME), can be derived from a variety of vegetable oils, animal fats, and used cooking oil [1-3]. Converting waste cooking oil (WCO) into biodiesel has become increasingly popular due to its economic and environmental benefits. Research has shown that biodiesel can be produced using base-catalyzed transesterification [4-6]. Biodiesel is regarded as an alternative energy source for diesel generators and other machines [7-9]. In Taiwan, the scale of the first demonstration factory for handling WCO has reached $3000 \mathrm{~m}^{3}$. WCO have also been used in commercial programs since October 2004 [10].

Sodium oxide and potassium oxide are commonly used as catalysts in the process of alkaline methanolysis for producing biodiesel [11]. Using a homogenous catalyst makes the mixture blend uniformly and shortens the reaction time. However, there are some problems in separating lipid catalysts and biodiesel [12]. Also, a large amount of water is required to balance the $\mathrm{pH}$ value of the waste liquid after the reaction, which greatly increases manufacturing costs. 
Heterogeneous catalyzed biodiesel production has become the preferred route because it is environmentally benign and needs no water washing, and product separation is relatively easy [13]. Various kinds of heterogeneous compound have been shown to be efficient catalysts. Examples include ETS-10 zeolites [14], modified zeolites [14,15], alkaline earth metal oxides [16,17], zinc oxide modified with alkali earth metals [18-20], $\mathrm{Na} / \mathrm{NaOH} / \gamma-\mathrm{Al}_{2} \mathrm{O}_{3}$ heterogeneous base catalyst [21], a mixture of alkali and alkaline metal, hydrotalcite [22-24], rare earth/lanthanide elements [25,26], ion exchange resin [27], and zirconia $[28,29]$. Bases derived from calcium have the most potential due to their low cost.

Liu et al. [30] carried out an experiment on producing biodiesel under conventional heating for $2 \mathrm{~h}$. Calcium methoxide was used as the catalyst in their study. A $98 \%$ biodiesel yield was obtained. Calcium methoxide has high catalytic activity and strong basicity. It is an alternative heterogeneous solid base catalyst. Moreover, it has a long catalyst lifetime, retaining its activity after 20 uses. However, the reaction requires a lot of time and energy under conventional heating. Their work examined several heterogeneous calcium compounds as a catalyst to produce methyl esters of WCO with the assistance of ultrasound.

Large-scale homogenizers are used in industry. Using a homogenizer significantly shortens the reaction time [31,32]. However, few studies have investigated the transesterification reaction of WCO for biodiesel production using a high-speed homogenizer [33]. In the present study, a homogenizer is used to quickly synthesize calcium methoxide. Then, the synthesized calcium methoxide is used as a catalyst to convert WCO. The optimal parameters are determined for this transesterification reaction.

\section{Experimental Section}

\subsection{Chemicals}

Sodium methoxide $\left(\mathrm{CH}_{3} \mathrm{OH}\right.$; purity: $\left.99.8 \%\right)$ was purchased from Nihon Shiyaku Reagent (Nihon Shiyaku Industries, Taipei City, Taiwan). Methyl laurate and hexane were purchased from Fluka (Uni-Onward Corp., New Taipei City, Taiwan). Calcium oxide $(\mathrm{CaO})$ was obtained from Riedel-De Haen (Uni-Onward Corp.) WCO was collected from fast-food restaurants.

\subsection{Catalyst Preparation}

The $\mathrm{Ca}\left(\mathrm{OCH}_{3}\right)_{2}$ catalyst synthesized with a traditional water-bath heating system was prepared as follows: commercial $\mathrm{CaO}(5.0 \mathrm{~g})$ was added into an Erlenmeyer flask with methanol $(100 \mathrm{~mL})$ under a reflux system at a temperature of $65^{\circ} \mathrm{C}$ and a rotation speed of $700 \mathrm{rpm}$ for $2 \mathrm{~h}$. After stirring, the solution was placed in a centrifuge at $5000 \mathrm{rpm}$ for $3 \mathrm{~min}$ to remove the methanol on the $\mathrm{CaO}$ surface. $\mathrm{Ca}\left(\mathrm{OCH}_{3}\right)_{2}$ was obtained after $1 \mathrm{~h}$ under a vacuum drying process at a temperature of $105^{\circ} \mathrm{C}$.

The $\mathrm{Ca}\left(\mathrm{OCH}_{3}\right)_{2}$ catalyst used in the experiment with a homogenizer system was processed as follows: commercial $\mathrm{CaO}(5.0 \mathrm{~g})$ was added into an Erlenmeyer flask with methanol $(100 \mathrm{~mL})$ under a homogenizer system, and then turned into a closed reflux system at a temperature of $65^{\circ} \mathrm{C}$ and a rotation speed of $700 \mathrm{rpm}$ for 30 to $60 \mathrm{~min}$. After the reaction, the solution placed in a centrifuge at $5000 \mathrm{rpm}$ for $3 \mathrm{~min}$ to remove the methanol on the $\mathrm{CaO}$ surface. The $\mathrm{Ca}\left(\mathrm{OCH}_{3}\right)_{2}$ was obtained after a vacuum drying process at a temperature of $105^{\circ} \mathrm{C}$ for $1 \mathrm{~h}$.

\subsection{Catalyst Characterization}

X-ray diffraction (XRD) was employed to observe the crystallography of the catalysts. XRD patterns of the samples were recorded on a D8 diffractometer (Bruker, Billerica, MA, USA) using $\mathrm{Cu} \mathrm{K} \alpha$ radiation. The patterns were recorded at a $2 \theta$ scanning rate of $0.04^{\circ} / \mathrm{s}$ in the $2 \theta$ range of $0^{\circ}$ to $60^{\circ}$. A PKI Spectrum GX Fourier transform infrared (FTIR) spectrophotometer (Wellesley, MA, USA) was used to identify the groups of $\mathrm{CaO}$. The spectra of the samples were recorded in the range of $400-4000 \mathrm{~cm}^{-1}$ with a resolution of $4 \mathrm{~cm}^{-1}$. The standard $\mathrm{KBr}$ technique was used for sample preparation. 


\subsection{Transesterification Reaction Procedure}

The experimental setup is shown in Figure 1. A homogenizer synthesis reactor (Hsiangtai H-M-300, Hsiangtai Co., Ltd., New Taipei City, Taiwan) equipped with a thermostatic tank and a condenser was used for the homogenizer reactions. The process was carried out under various operation conditions. The operating parameters include reaction temperature, amount of catalyst, reaction time, methanol-to-oil molar ratio, and rotation speed. A conventional heating system (HTS-1003, Laboratory \& Medical Supplies Co., Ltd., Tokyo, Japan) equipped with a mechanical stirrer and a condenser (LC-10, Hi-point Co., Ltd., Kaohsiung City, Taiwan) was used for the conventional heating reactions.

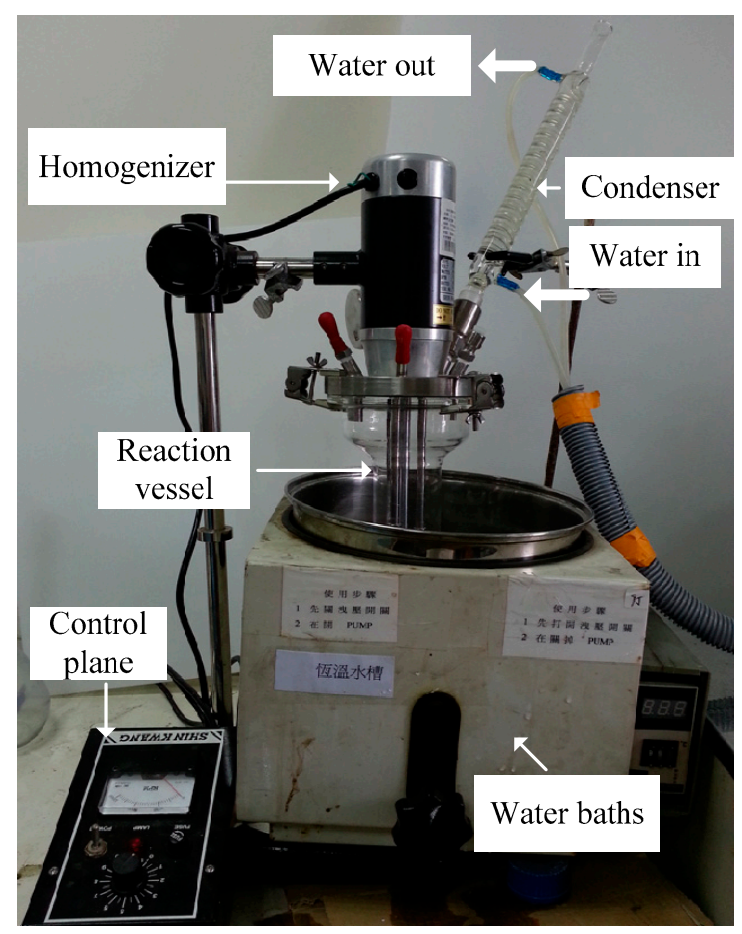

Figure 1. The experimental setup.

The acid value $(A V)$ and saponification value $(S V)$ were determined using a standard American Oil Chemists' Society (AOCS) titrimetry method. $A V$ was measured as follows: the oil (5.0 g) was added into an alcohol/ether solution $(1: 1 ; \mathrm{v} / \mathrm{v}, 150 \mathrm{~mL})$ in a $250 \mathrm{~mL}$ Erlenmeyer flask; then, a few drops of $1 \%$ phenolphthalein indicator was added into the solution. Finally, titration was conducted with $0.1 \mathrm{~N}$ potassium hydroxide solution. $S V$ was measured as follows: the oil ( $2.0 \mathrm{~g})$ was added into a potassium hydroxide/alcohol solution $(1: 1 ; \mathrm{v} / \mathrm{v}, 25 \mathrm{~mL})$ in a $250 \mathrm{~mL}$ Erlenmeyer flask. The solution was refluxed with heat for $1 \mathrm{~h}$. Then, a few drops of $1 \%$ phenolphthalein indicator were added into the solution. Finally, titration was conducted with $0.5 \mathrm{~N}$ hydrochloric acid. The $A V$ of WCO was calculated as [33]:

$$
A V=\frac{5.61 \times V_{\mathrm{NaOH}}}{W}
$$

where $V_{\mathrm{NaOH}}$ is the volume of the sodium hydroxide titrant $(\mathrm{mL})$ and $W$ is the oil weight $(\mathrm{g})$.

The $S V$ of WCO was calculated as [33]:

$$
S V=\frac{(B-S) \times 56.1 \times 0.5}{W}
$$

where $S$ is sample titration amount $(\mathrm{mL}) ; B$ is the blank titration amount $(\mathrm{mL})$, and $W$ is the oil weight (g). 
The molecular weight $(M W)$ of $\mathrm{WCO}$ was calculated from its $S V$ and $A V[33,34]$ as:

$$
M W=56.1 \times 1000 \times \frac{3}{(S V-A V)},
$$

where $S V$ and $A V$ are in units of $\mathrm{mg} \mathrm{KOH} / \mathrm{g}$. The $A V, S V$, and $M W$ of the WCO used here are $0.062 \mathrm{mg}$ $\mathrm{KOH} / \mathrm{g}, 223.558 \mathrm{mg} \mathrm{KOH} / \mathrm{g}$, and 753.03, respectively. Therefore, the WCO moles can be obtained by dividing the mass by the molecular weight $(M W)$.

The WCO was kept at a constant mass (mole) when running the experiments with different methanol to oil ratios. A $100 \mathrm{~g}$ sample of $\mathrm{WCO}$, as a reactant, was put into a $500 \mathrm{~mL}$ reactant tank. A homogenizer was used to promote the uniformity of the reaction in the system. The experiment was carried out at temperatures ranging from 50 to $70{ }^{\circ} \mathrm{C}$, a catalyst content of 1 to $5 \mathrm{wt} \%$ (based on the weight of WCO), reaction times of 30 to $90 \mathrm{~min}$, various methanol-to-oil molar ratios (4:1, 6:1, 8:1, and 10:1), and various rotation speeds (1000, 3000, 5000, 7000, and $9000 \mathrm{rpm})$. After the reaction, the upper layer was biodiesel and the lower layer was glycerol. The material (biodiesel) was dried in an oven at $105^{\circ} \mathrm{C}$ for $6 \mathrm{~h}$.

\subsection{Analytical Methods}

The analytical method used to determine the content of FAME followed the Taiwan CNS-15051 standard. Similar studies using this method were found [33,35-38]. The biodiesel sample was analyzed with a Clarus 600 GC (PerkinElmer, Shelton, CT, USA) equipped with a capillary column (SPBTM-WAX, $30 \mathrm{~m} \times 0.75 \mathrm{~m} \times 1.0 \mu \mathrm{m}$ ) and a flame ionization detector (FID). The FAME standards for GC calibration were methyl myristate (C14:0), methyl palmitate (C16:0), methyl palmitoleate (C16:1), methyl heptadecanoate (C17:0 used as the internal standard [37]), methyl stearate (C18:0), methyl oleate (C18:1), methyl linoleate (C18:2), methyl linolenate (C18:3), methyl arachidate (C20:0), methyl eicosapentaenoate (C20:5), and methyl behenate (C22:0). Their retention times were used to identify and confirm the chromatogram FAME peaks obtained from the samples.

In this experiment, $50 \mathrm{mg}$ of the sample was mixed evenly with $1 \mathrm{~mL}$ of the internal standard, and a small portion of the sample $(1 \mu \mathrm{L})$ was injected under the following conditions: the injector temperature was $280^{\circ} \mathrm{C}$ with a split ratio of 1:20; nitrogen was used as the carrier gas with a flow rate of $45 \mathrm{~mL} / \mathrm{min}$; the air flow rate was $450 \mathrm{~mL} / \mathrm{min}$, and the temperature of the detector was $300{ }^{\circ} \mathrm{C}$. The oven temperature was initially set at $210{ }^{\circ} \mathrm{C}$, held for $4 \mathrm{~min}$, and then increased to $240{ }^{\circ} \mathrm{C}$ at a rate of $4{ }^{\circ} \mathrm{C} / \mathrm{min}$, and held there for $8 \mathrm{~min}$. Finally, the peak areas after gas chromatography analysis were compared, and the conversion of WCO to biodiesel was calculated following the standard method EN 14103, which is defined as follows:

$$
C=\frac{\left(\sum A\right)-A_{E I}}{A_{E I}} \times \frac{A_{E I} \times V_{E I}}{m} \times 100 \%,
$$

where $\Sigma A$ is the total peak area from FAME $C_{14: 0}$ to $C_{24: 1} ; A_{E I}$ is the peak area of the internal standard (methyl heptadecanoate); $C_{E I}$ is the concentration of the internal standard $(\mathrm{mg} / \mathrm{mL}) ; V_{E I}$ is the volume of the internal standard $(\mathrm{mL})$, and $m$ is the mass of the sample $(\mathrm{mg})$ to be analyzed. The data on conversion rate were obtained by averaging three individual measurements, and the standard deviations were shown with error bars.

\section{Results and Discussion}

\subsection{Characterization of the Catalyst}

The XRD patterns of $\mathrm{Ca}\left(\mathrm{OCH}_{3}\right)_{2}$ synthesized for $2 \mathrm{~h}$ using the conventional water-bath heating system and $\mathrm{Ca}\left(\mathrm{OCH}_{3}\right)_{2}$ synthesized for 30 or 60 min with a homogenizer are shown in Figure 2. The obvious peaks shown in Figure $2 \mathrm{a}$ at $32.1^{\circ}$ and $37.5^{\circ}(2 \theta)$ are consistent with $\mathrm{CaO}$ (JCPDS 37-1497). The commercial $\mathrm{CaO}$ used in this study was very pure and therefore did not contain 
$\mathrm{CaCO}_{3}$. Accordingly, in the XRD patterns of the commercial $\mathrm{CaO}$ (Figure 2a), a prominent peak (indicated with a black square) in the $37-38^{\circ}(2 \theta)$ range is not observed. As shown in Figure $2 b, c$, the intensity of the reflections decreased, indicating that the $\mathrm{CaO}$ reacted completely with methanol in the synthesis reaction. Based on Equation (5), $\mathrm{CaO}$ was consumed by methanol either in part or completely in this reaction. The peak corresponding to the $\mathrm{CaO}$ phases disappeared after the reaction. Additionally, the $\mathrm{CaO}$ might have contacted atmospheric air and reacted with $\mathrm{H}_{2} \mathrm{O}$ and $\mathrm{CO}_{2}$ through chemisorption. Eventually, very small amounts of $\mathrm{Ca}(\mathrm{OH})_{2}$ and $\mathrm{CaCO}_{3}$, were produced through hydroxylation and the carbonation reaction, respectively [39]. Hence, in the other two spectra shown in Figure $2 b, c$, the intensity of the peak corresponding to the $\mathrm{CaCO}_{3}$ phases is very low. However, as shown in Figure $2 \mathrm{~d}$, the reaction was not complete after $30 \mathrm{~min}$ in the homogenizer system. The reflections at $32.1^{\circ}$ and $37.5^{\circ}(2 \theta)$ indicate that the $\mathrm{CaO}$ had not totally reacted. Also, a slightly more prominent peak in the $37-38^{\circ}$ range corresponding to the $\mathrm{CaCO}_{3}$ phases was observed. For the $\mathrm{Ca}\left(\mathrm{OCH}_{3}\right)_{2}$ catalyst synthesized using the conventional method or the homogenizer system, the most remarkable peak for $\mathrm{Ca}\left(\mathrm{OCH}_{3}\right)_{2}$ was at $11^{\circ}(2 \theta)$. The peak of $\mathrm{Ca}\left(\mathrm{OCH}_{3}\right)_{2}$ is similar to that shown in reference [40]. A comparison of the main peaks between Figure $2 b, c$ indicated that there was only a slight difference in the peak area. This suggests that the homogenizer system can synthesize $\mathrm{Ca}\left(\mathrm{OCH}_{3}\right)_{2}$ more rapidly and effectively than conventional water-bath heating. The reaction time for the traditional method was double that for the homogenizer method. In addition, the diffraction peak at $18^{\circ}(2 \theta)$ is a feature of $\mathrm{Ca}(\mathrm{OH})_{2}$ and that at $29.2^{\circ}(2 \theta)$ is a feature of $\mathrm{CaCO}_{3}$. Both of them are byproducts in Equation (5). This might be a result of oxidation during synthesis [40].

$$
\mathrm{CaO}+2 \mathrm{CH}_{3} \mathrm{OH} \rightarrow \mathrm{Ca}\left(\mathrm{OCH}_{3}\right)_{2}+\mathrm{H}_{2} \mathrm{O}
$$

The infrared (IR) spectra of the $\mathrm{Ca}\left(\mathrm{OCH}_{3}\right)_{2}$ synthesized for $2 \mathrm{~h}$ using the conventional system and $\mathrm{Ca}\left(\mathrm{OCH}_{3}\right)_{2}$ synthesized for 30 or $60 \mathrm{~min}$ with the homogenizer are shown in Figure 3 . The characteristic absorption between 1050 and $1085 \mathrm{~cm}^{-1}$ indicates the presence of the $\mathrm{C}-\mathrm{O}$ in the alcohol. The other characteristic absorption between 3700 and $3580 \mathrm{~cm}^{-1}$ represents the existence of the strong and wide $-\mathrm{OH}$ mode. This peak corresponds to the $-\mathrm{OH}$ mode of water [41]. For the absorption at $1080 \mathrm{~cm}^{-1}$ in Figure $3 a, b$, the bands are almost the same. However, the peak intensity is weaker in Figure $3 c$. This is attributed to the incomplete reaction in Equation (5). Furthermore, Granados et al. [17] pointed out the important feature between 2800 and $3000 \mathrm{~cm}^{-1}$ and $1480 \mathrm{~cm}^{-1}$ is observed as $-\mathrm{C}-\mathrm{H}$, also one of the characteristic peaks of the $\mathrm{CH}_{3}$ in methanol.

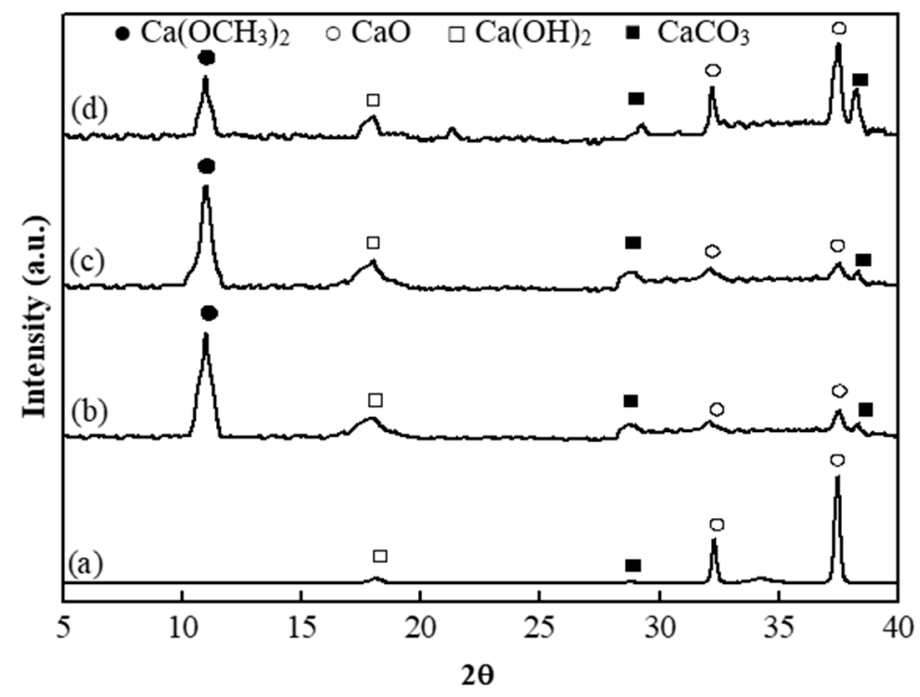

Figure 2. XRD patterns of (a) commercial $\mathrm{CaO}$, (b) $\mathrm{Ca}\left(\mathrm{OCH}_{3}\right)_{2}$ synthesized for $2 \mathrm{~h}$ using conventional water-bath heating, and $\mathrm{Ca}\left(\mathrm{OCH}_{3}\right)_{2}$ synthesized using a homogenizer for (c) $60 \mathrm{~min}$ and (d) $30 \mathrm{~min}$. 


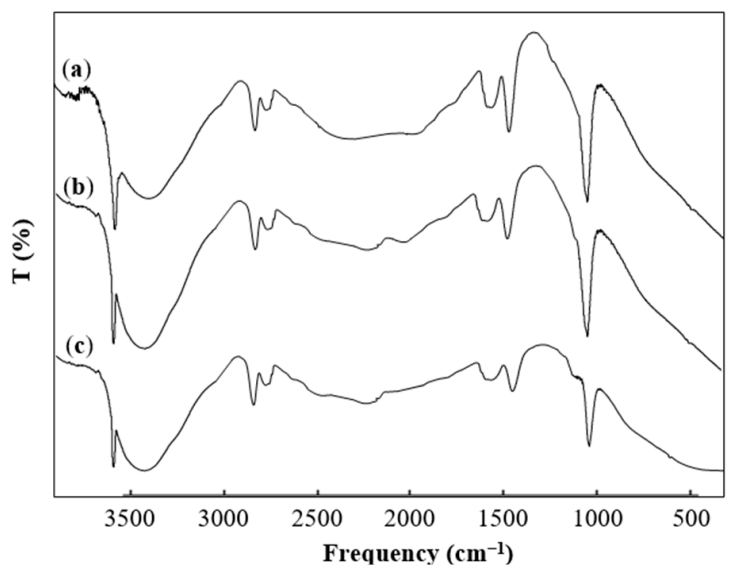

Figure 3. IR analysis of (a) $\mathrm{Ca}\left(\mathrm{OCH}_{3}\right)_{2}$ synthesized using conventional water-bath heating for $2 \mathrm{~h}$ and $\mathrm{Ca}\left(\mathrm{OCH}_{3}\right)_{2}$ synthesized using a homogenizer (b) $60 \mathrm{~min}$ and (c) $30 \mathrm{~min}$.

\subsection{Effects of Rotation Speed on the Conversion Rate of Biodiesel}

The previous experimental results show that the reaction of $\mathrm{CaO}$ and methanol using the homogenizer system for 60 min gave the best conversion for $\mathrm{Ca}\left(\mathrm{OCH}_{3}\right)_{2}$ catalyst. This product was used as the base solid catalyst in subsequent experiments.

The effects of rotation speed on the conversion rate of the biodiesel are shown in Figure 4. As shown, the rotation speed influenced the reaction. The experiment was carried out with various rotation speeds $(1000,3000,5000,7000$, and $9000 \mathrm{rpm})$, a methanol-to-oil ratio of $6: 1$, a reaction temperature of $65{ }^{\circ} \mathrm{C}$, $4 \mathrm{wt} \% \mathrm{Ca}\left(\mathrm{OCH}_{3}\right)_{2}$ catalyst synthesized using the homogenizer system for $60 \mathrm{~min}$, and a reaction time of $60 \mathrm{~min}$. The reactants did not react completely at low rotation speed (1000 rpm); therefore, the conversion rate was relatively low, only $12.4 \%$. As the rotation speed was increased, the conversion rate increased approximately linearly for 1000 to $7000 \mathrm{rpm}$. This increasing trend is due to the increase in the number of collisions between particles. Increasing of the rotation speed enhanced the contact area between reactants and made the WCO, methanol, and catalyst mix evenly. When the rotation speed was increased to 7000 $\mathrm{rpm}$, the conversion rate was $76.7 \%$. Further increasing the rotation speed increased the conversion rate. However, considering the problem of the homogenizer overheating, the optimal rotation speed was 7000 $\mathrm{rpm}$. Therefore, in the subsequent experiments, we used a fixed rotation speed (7000 rpm) to determine the optimal conditions for the highest conversion by adjusting the methanol-to-oil molar ratio, catalyst loading, reaction temperature, and reaction time.

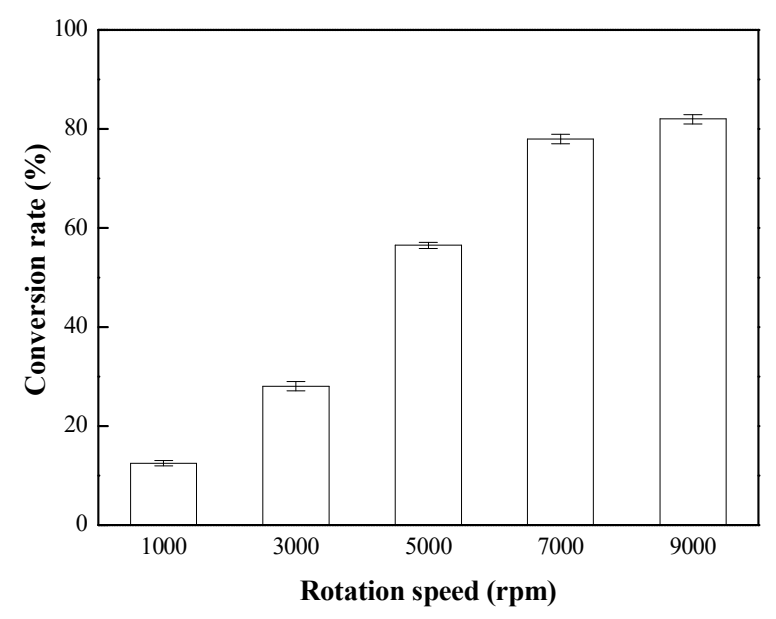

Figure 4. Effect of rotation speed on the transesterification reaction. Reaction condition: methanol/oil molar ratio 6:1, catalyst amount $4 \mathrm{wt} \%$, reaction temperature $65^{\circ} \mathrm{C}$, reaction time $60 \mathrm{~min}$, rotation speed 1000-9000 rpm. 


\subsection{Effects of Methanol-to-Oil Molar Ratio on the Conversion Rate of Biodiesel}

The effects of the methanol-to-oil molar ratio on the conversion rate are shown in Figure 5. Experiments were carried out with various methanol-to-oil molar ratios (4:1, 6:1, 8:1, and 10:1), $4 \mathrm{wt} \%$ $\mathrm{Ca}\left(\mathrm{OCH}_{3}\right)_{2}$ catalyst, a reaction temperature of $65^{\circ} \mathrm{C}$, a reaction time of $60 \mathrm{~min}$, and a rotation speed of $7000 \mathrm{rpm}$ to investigate the influence of the molar ratio on the conversion rate. As mentioned above, the WCO was kept at a constant mole when running the experiments with various methanol-to-oil molar ratios. Figure 5 shows that the conversion rate of the biodiesel increased with the methanol-to-oil molar ratio for ratios of 4:1 to 10:1. When the methanol-to-oil molar ratio was $4: 1$, the reaction did not reach a balance, causing the conversion rate to be low. The conversion rate was $53.5 \%$. When the methanol-to-oil ratio was increased to $6: 1$, the conversion rate was $76.8 \%$. When the methanol-to-oil ratio was further increased to $8: 1$ and 10:1, the conversion rate decreased. These results were attributed to excess methanol promoting the reverse reaction and diluting the concentration of the catalyst. That is, the results can be explained by the fact that glycerol is soluble in alcohol. Hence, an excess of methanol can increase the concentration of glycerol in the reaction mixture, which can shift the equilibrium to the reactant side [36]. Furthermore, glycerol and biodiesel are miscible due to the use of excess methanol [33]. In this situation, the opportunity for the catalyst and oil particles to collide decreased. The reaction could not be carried out efficiently, and thus the conversion was lower $[33,36,42]$. The optimal methanol-to-oil ratio was 6:1.

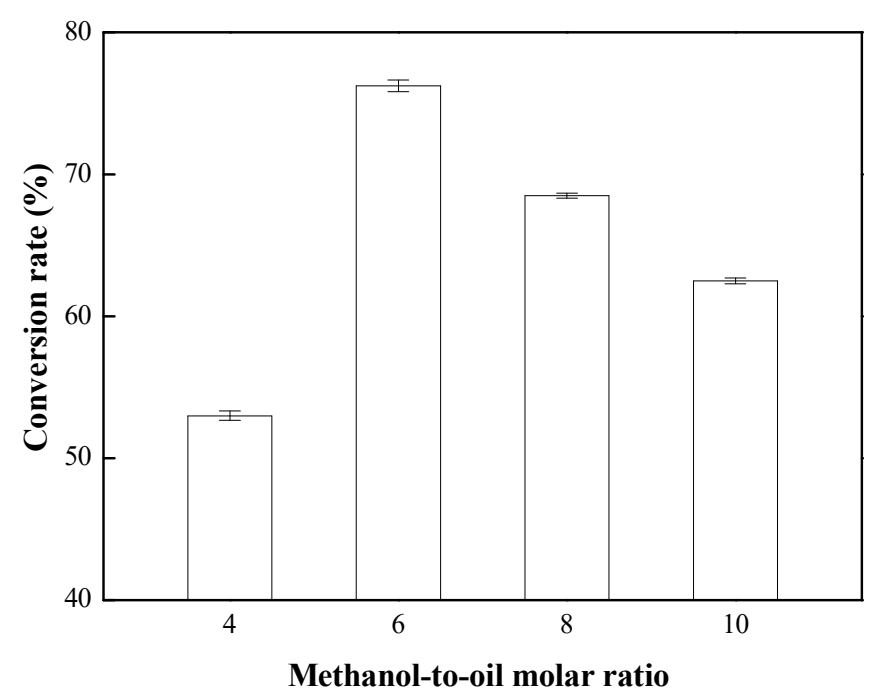

Figure 5. Effect of methanol-to-oil molar ratio on the transesterification reaction. Reaction conditions: catalyst amount: $4 \mathrm{wt} \%$; rotation speed: $7000 \mathrm{rpm}$; reaction temperature: $65{ }^{\circ} \mathrm{C}$; reaction time: $60 \mathrm{~min}$; methanol-to-oil molar ratio: 4:1-10:1.

\subsection{Effects of Amount of Catalyst on the Conversion Rate of Biodiesel}

The effects of the amount of catalyst on the conversion rate are shown in Figure 6. The experiment was carried out with various amounts of $\mathrm{Ca}\left(\mathrm{OCH}_{3}\right)_{2}(1,2,3,4$, and $5 \mathrm{wt} \%)$ synthesized using the homogenizer system for $60 \mathrm{~min}$, a methanol-to-oil ratio of 6:1, a reaction time of $60 \mathrm{~min}$, a temperature of $65{ }^{\circ} \mathrm{C}$, and a rotation speed of $7000 \mathrm{rpm}$. When the amount of catalyst was increased from $1 \mathrm{wt} \%$ to $4 \mathrm{wt} \%$, the opportunity of collisions between the catalyst and reactant particles increased, promoting the formation of the biodiesel. Gryglewicz [41] found that alkaline-earth metal alkoxides are slightly soluble in alcohols when they are more than $0.04 \mathrm{wt} \%$ in the liquid. Therefore, alcohol can be catalyzed not only by free alkoxylate ions but also by solid alkoxylate, which can be regarded as abducts. An alkoxide can be introduced directly into the reaction system. Alkoxides have been found to be highly catalytically active in such cases. $\mathrm{Ca}\left(\mathrm{OCH}_{3}\right)_{2}$ has strong basicity. When the catalyst was added at $5 \mathrm{wt} \%$, the conversion of the biodiesel decreased by about $10 \%$. This can possibly be attributed to a 
mixing problem involving the reactants and the solid catalyst. The excess amount of catalyst led to an increase in the viscosity of the reaction mixture, resulting in the poor diffusion of the reactants in the methanol-oil-catalyst systems, thus causing the lower conversion rate [21,42-44]. Therefore, the optimal catalyst content was 4 wt \%.

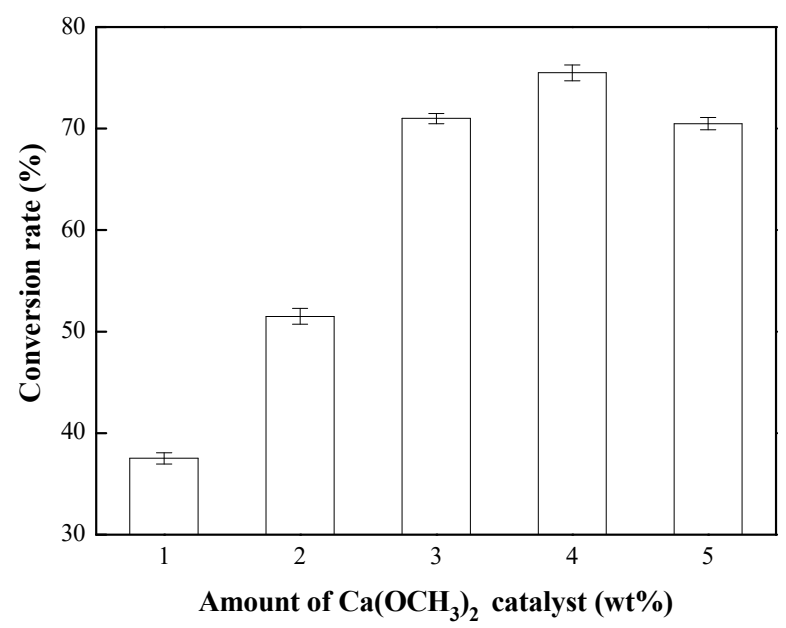

Figure 6. Effect of catalyst amount on the transesterification reaction. Reaction conditions: methanol-to-oil molar ratio: 6:1; rotation speed: $7000 \mathrm{rpm}$; reaction temperature: $65^{\circ} \mathrm{C}$; reaction time: $60 \mathrm{~min}$; catalyst amount: $1-5$ wt \%.

\subsection{Effects of Temperature on the Conversion Rate of Biodiesel}

The effects of temperature on the conversion rate of biodiesel are shown in Figure 7. The experiment was carried out with temperatures of 50 to $70{ }^{\circ} \mathrm{C}, 4 \mathrm{wt} \% \mathrm{Ca}\left(\mathrm{OCH}_{3}\right)_{2}$ catalyst synthesized using the homogenizer system for $60 \mathrm{~min}$, a methanol-to-oil ratio of 6:1, a reaction time of $60 \mathrm{~min}$, and a rotation speed of $7000 \mathrm{rpm}$. The conversion rates at 50 and $55{ }^{\circ} \mathrm{C}$ were $22.8 \%$ and $29.1 \%$, respectively. When the temperature was increased to $60^{\circ} \mathrm{C}$, the conversion rate of the biodiesel increased to $50.9 \%$. At a temperature of $65{ }^{\circ} \mathrm{C}$, the conversion rate was $76.7 \%$. Note that the conversion rate reached a maximum at $65^{\circ} \mathrm{C}$ with increasing temperature and then decreased slightly after $65^{\circ} \mathrm{C}$. This might be related to the boiling point of the methanol $\left(64.7^{\circ} \mathrm{C}\right)$. When the reaction temperature was above the critical point (boiling point), methanol vaporized easily in the reaction tank, inhibiting the reaction between methanol, WCO, and the catalyst. More specifically, this phenomenon could be attributed to a large amount of methanol vaporized in the gas phase as well as a sharp decrease in methanol in the liquid phase at a higher temperature than the boiling point of methanol $[44,45]$. In addition, too high of a reaction temperature will increase the risk of saponification [44]. Accordingly, the optimal reaction temperature was $65^{\circ} \mathrm{C}$.

\subsection{Effects of Reaction Time on the Conversion Rate of Biodiesel}

The effects of the reaction time on the conversion rate of the biodiesel are shown in Figure 8. The experiment was carried out with various reaction times (30, 45, 60, 75, and $90 \mathrm{~min})$, a methanol-to-oil ratio of 6:1, a reaction temperature of $65{ }^{\circ} \mathrm{C}, 4 \mathrm{wt} \% \mathrm{Ca}\left(\mathrm{OCH}_{3}\right)_{2}$ catalyst, and a rotation speed of $7000 \mathrm{rpm}$. Figure 8 shows that the reactants did not efficiently undergo transesterification in $30 \mathrm{~min}$; the conversion rate was below $20 \%$. When the reaction time was increased to $60 \mathrm{~min}$, the conversion rate increased significantly to $76.7 \%$. The reason for this increase is the increase in reaction time. The reactants could be mixed much more evenly. Further increasing the reaction time from 60 to $90 \mathrm{~min}$ led to gradual increase in the conversion rate. When the reaction time was $90 \mathrm{~min}$, the conversion rate reached $90.2 \%$. The optimal reaction time was $90 \mathrm{~min}$. In summary, the optimal reaction conditions are a methanol-to-oil molar ratio of 6:1, $4 \mathrm{wt} \% \mathrm{Ca}\left(\mathrm{OCH}_{3}\right)_{2}$, a reaction temperature of $65^{\circ} \mathrm{C}$, a rotation speed of $7000 \mathrm{rpm}$, and a reaction time of $90 \mathrm{~min}$. 


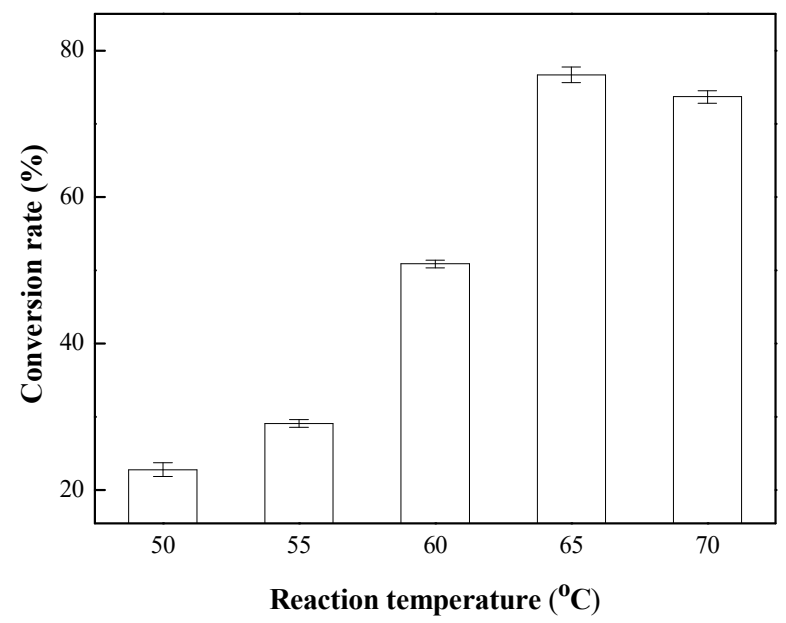

Figure 7. Effect of reaction temperature on the transesterification reaction. Reaction conditions: methanol-to-oil molar ratio: 6:1; catalyst amount: $4 \mathrm{wt} \%$; rotation speed: $7000 \mathrm{rpm}$; reaction time: $60 \mathrm{~min}$; reaction temperature: $50-70{ }^{\circ} \mathrm{C}$.

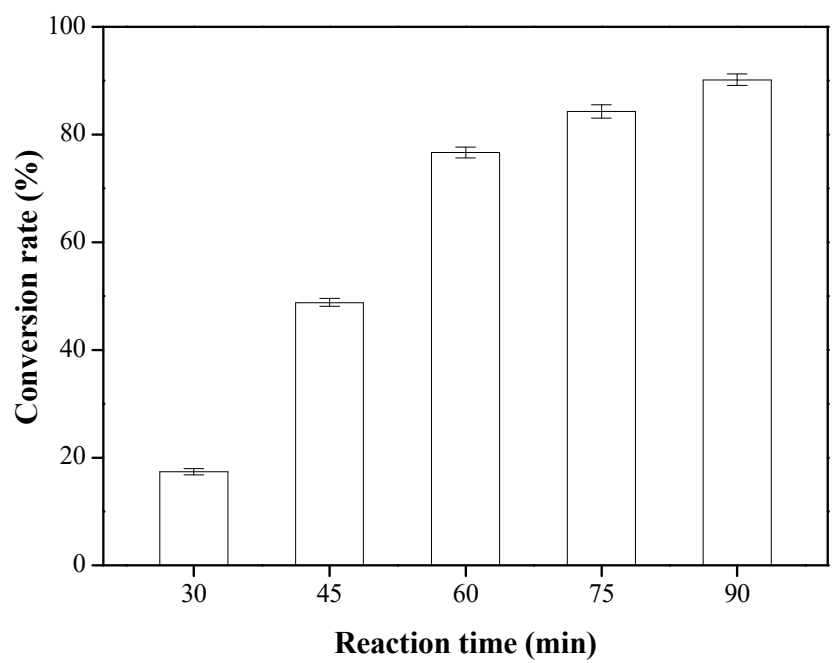

Figure 8. Effect of reaction time on the transesterification reaction. Reaction conditions: methanol-to-oil molar ratio: 6:1; catalyst amount: $4 \mathrm{wt} \%$; rotation speed: $7000 \mathrm{rpm}$; reaction temperature: $65{ }^{\circ} \mathrm{C}$; reaction time: 30-90 $\mathrm{min}$.

\section{Conclusions}

This study investigated synthesizing $\mathrm{Ca}\left(\mathrm{OCH}_{3}\right)_{2}$ using a homogenizer system for a transesterification reaction. Calcium methoxide was synthesized using a homogenizer system for $60 \mathrm{~min}$. Compared to conventional water-bath heating, the reaction time was decreased by half. The chemical composition of the catalysts was examined using XRD and IR spectroscopy. The WCO underwent a transesterification reaction with the catalyst synthesized using a homogenizer system to reduce the reaction time. The optimal conditions for this experiment were a methanol-to-oil molar ratio of $6: 1,4 \mathrm{wt} \% \mathrm{Ca}\left(\mathrm{OCH}_{3}\right)_{2}$ catalyst, a reaction temperature of $65{ }^{\circ} \mathrm{C}$, a rotation speed of $7000 \mathrm{rpm}$, and a reaction time of $90 \mathrm{~min}$. Under these conditions, the conversion rate of the biodiesel reached $90.2 \%$. In addition, the large amount of waste water required in the oil-water separation step could be reduced by using calcium methoxide instead of a homogeneous catalyst, significantly lowering manufacturing costs. Homogenizers can increase scale and effectively shorten the reaction time. The proposed method is highly competitive with conventional homogenous catalysts and the heating-stirring method. 
Author Contributions: J.-Y.K. and P.-H.H. performed the experiments and analyzed the results. M.-C.H. contributed to the structure, organization, and presentation of the work. S.-S.H. contributed ideas, designed experiments, analyzed results, prepared the manuscript, and help with editing the manuscript.

Funding: This research was funded by the Ministry of Science and Technology, Taiwan, under grant number MOST 107-2637-E-168-001.

Acknowledgments: The authors would like to thank H.P. Wang of the Department of Environmental Engineering, National Cheng Kung University, Tainan, Taiwan, for his assistance in the experiments.

Conflicts of Interest: The authors declare no conflicts of interest.

\section{References}

1. Demirbas, A. Biodiesel production from vegetable oils via catalytic and non-catalytic supercritical methanol transesterification methods. Prog. Energy Combust. Sci. 2005, 31, 466-487. [CrossRef]

2. Graboski, M.S.; McCormick, R.L. Combustion of fat and vegetable oil derived fuels in diesel engines. Prog. Energy Combust. Sci. 1998, 24, 125-164. [CrossRef]

3. Bozbas, K. Biodiesel as an alternative motor fuel: Production and policies in the European Union. Renew. Sustain. Energy Rev. 2008, 12, 542-552. [CrossRef]

4. Mittelbach, M.; Enzelsberger, H. Transesterification of heated rapeseed oil for extending diesel fuel. J. Am. Oil Chem. Soc. 1999, 76, 545-550. [CrossRef]

5. Alcantara, R.; Amores, J.; Canoira, L.; Fidalgo, E.; Franco, M.J.; Navarro, A. Catalytic production of biodiesel from soybean oil, used frying oil and tallow. Biomass Bioenergy 2000, 18, 515-527. [CrossRef]

6. Mittelbach, M.; Gangl, S. Long storage stability of biodiesel made from rapeseed and used frying oil. J. Am. Oil Chem. Soc. 2001, 78, 573-577. [CrossRef]

7. Murayama, T.; Fujiwara, Y.; Noto, T. Evaluating waste vegetable oils as a diesel fuel. Proc. Inst. Mech. Eng. Part D J. Automob. Eng. 2000, 214, 141-148. [CrossRef]

8. Dorado, M.P.; Ballesteros, E.; Arnal, J.M.; Gomez, J.; Lopez Gimenez, F.J. Testing waste olive oil methyl ester as a fuel in a diesel engine. Energy Fuels 2001, 17, 1560-1565. [CrossRef]

9. Tashtoush, G.; AlWidyan, M.I.; AlShyoukh, A.O. Combustion performance and emissions of ethyl ester of a waste vegetable oil in a water-cooled furnace. Appl. Therm. Eng. 2003, 23, 285-293. [CrossRef]

10. Hsien, H.T. Green energy-biodiesel demonstration plant. Energy Mag. 2004, 12, 22-24. (In Chinese)

11. Meher, L.C.; Sagar, D.V.; Naik, S.N. Technical aspects of biodiesel production by transesterification-A review. Renew. Sustain. Energy Rev. 2006, 10, 248-268. [CrossRef]

12. Ghadge, S.V.; Raheman, H. Biodiesel production from mahua (Madhuca indica) oil having high free fatty acids. Biomass Bioenergy 2005, 2, 601-605. [CrossRef]

13. Semwal, S.; Arora, A.K.; Badoni, R.P.; Tuli, D.K. Biodiesel production using heterogeneous catalysts. Bioresour. Technol. 2011, 102, 2151-2161. [CrossRef] [PubMed]

14. Suppes, G.J.; Dasari, M.A.; Doskocil, E.J.; Mankidy, P.J.; Goff, M.J. Transesterification of soybean oil with zeolite and metal catalysts. Appl. Catal. A 2004, 257, 213-223. [CrossRef]

15. Jitputti, J.; Kitiyanan, B.; Rangsunvigit, P.; Bunyakiat, K.; Attanatho, L.; Jenvanitpanjakul, P. Transesterification of crude palm kernel oil and crude coconut oil by different solid catalysts. Chem. Eng. J. 2006, 116, 61-66. [CrossRef]

16. Wang, L.; Yang, J. Transesterification of soybean oil with nano-MgO or not in supercritical and subcritical methanol. Fuel 2007, 8, 328-333. [CrossRef]

17. Granados, M.L.; Poves, M.; Alonso, D.M.; Mariscal, R.; Galisteo, F.C.; Moreno-Tost, R. Biodiesel from sunflower oil by using activated calcium oxide. Appl. Catal. B 2007, 73, 317-326. [CrossRef]

18. Yang, Z.; Xie, W. Soybean oil transesterification over zinc oxide modified with alkali earth metals. Fuel Process. Technol. 2007, 88, 631-638. [CrossRef]

19. Xie, W.; Yang, Z. Ba-ZnO catalysts for soybean oil transesterification. Catal. Lett. 2007, 117, 159-165. [CrossRef]

20. Albuquerque, M.C.G.; Jiménez-Urbistondo, I.; Santamaría-González, J.; Mérida-Robles, J.M.; Moreno-Tost, R.; Rodríguez-Castellón, E.; Rodríguez-Castellón, E.; Jiménez-López, A.; Azevedo, D.C.S.; Cavalcante, C.L., Jr.; et al. $\mathrm{CaO}$ supported on mesoporous silicas as basic catalysts for transesterification reactions. Appl. Catal. A 2008, 334, 35-43. [CrossRef] 
21. Kim, H.J.; Kang, B.S.; Kim, M.J.; Park, Y.M.; Kim, D.K.; Lee, J.S. Transesterification of vegetable oil to biodiesel using heterogeneous base catalyst. Catal. Today 2004, 93, 315-320. [CrossRef]

22. Cantrell, D.G.; Gillie, L.J.; Lee, A.F.; Wilson, K. Structure-reactivity correlations in MgAl hydrotalcite catalysts for biodiesel synthesis. Appl. Catal. A 2005, 287, 183-190. [CrossRef]

23. Gao, L.; Teng, G.; Xiao, G.; Wei, R. Biodiesel from palm oil via loading KF/Ca-Al hydrotalcite catalyst. Biomass Bioenergy 2010, 34, 1283-1288. [CrossRef]

24. Dias, A.P.S.; Bernardo, J.; Felizardo, P.; Correia, M.J.N. Biodiesel production over thermal activated cerium modified Mg-Al hydrotalcites. Energy 2012, 41, 344-353. [CrossRef]

25. Li, X.; Lu, G.; Guo, Y.; Wang, Y.; Zhang, Z.; Liu, X. A novel solid superbase of $\mathrm{Eu}_{2} \mathrm{O}_{3} / \mathrm{Al}_{2} \mathrm{O}_{3}$ and its catalytic performance for the transesterification of soybean oil to biodiesel. Catal. Commun. 2007, 8, 1969-1972. [CrossRef]

26. Thitsartarn, W.; Kawi, S. An active and stable $\mathrm{CaO}-\mathrm{CeO}_{2}$ catalyst for transesterification of oil to biodiesel. Green Chem. 2011, 13, 3423-3430. [CrossRef]

27. Shibasaki-Kitakawa, N.; Honda, H.; Kuribayashi, H.; Toda, T.; Fukumura, T.; Yonemoto, T. Biodiesel production using anionic ion-exchange resin as heterogeneous catalyst. Bioresour. Technol. 2007, 98, 416-421. [CrossRef] [PubMed]

28. Sun, H.; Ding, Y.; Duan, J.; Zhang, Q.; Wang, Z.; Lou, H. Transesterification of sunflower oil to biodiesel on ZrO2 supported La2O3 catalyst. Bioresour. Technol. 2010, 101, 953-958. [CrossRef] [PubMed]

29. Wan Omar, W.N.N.; Amin, N.A.S. Biodiesel production from waste cooking oil over alkaline modified zirconia catalyst. Fuel Process. Technol. 2011, 92, 2397-2405. [CrossRef]

30. Liu, X.; Piao, X.; Wang, Y.; Zhu, S.; He, H. Calcium methoxide as a solid base catalyst for the transesterification of soybean oil to biodiesel with methanol. Fuel 2008, 87, 1076-1082. [CrossRef]

31. Huppertz, T. Homogenization of Milk-Other Types of Homogenizer (High-Speed Mixing, Ultrasonics Microfluidizers, Membrane Emulsification). In Encyclopedia of Dairy Sciences, 2nd ed.; Fuquay, J.W., Fox, P.F., McSweeney, P.L.H., Eds.; Elsevier: Oxford, UK; Academic Press: Oxford, UK, 2011; pp. 761-764.

32. Saheki, A.; Seki, J.; Nakanishi, T.; Tamai, I. Effect of back pressure on emulsification of lipid nanodispersions in a high-pressure homogenizer. Int. J. Pharm. 2012, 422, 489-494. [CrossRef] [PubMed]

33. Hsiao, M.C.; Kuo, J.Y.; Hsieh, P.H.; Hou, S.S. Improving biodiesel conversions from blends of high-and low-acid-value waste cooking oils using sodium methoxide as a catalyst based on a high speed homogenizer. Energies 2018, 11, 2298. [CrossRef]

34. Anastopoulos, G.; Zannikou, Y.; Stournas, S.; Kalligeros, S. Transesterification of vegetable oils with ethanol and characterization of the key fuel properties of ethyl esters. Energies 2009, 2, 362-376. [CrossRef]

35. Hsiao, M.C.; Lin, C.C.; Chang, Y.H.; Chen, L.C. Ultrasonic mixing and closed microwave irradiation-assisted transesterification of soybean oil. Fuel 2010, 89, 3618-3622. [CrossRef]

36. Hsiao, M.C.; Lin, C.C.; Chang, Y.H. Microwave irradiation-assisted transesterification of soybean oil to biodiesel catalyzed by nanopowder calcium oxide. Fuel 2011, 90, 1963-1967. [CrossRef]

37. Kuan, I.; Kao, W.C.; Chen, C.L.; Yu, C.Y. Microbial biodiesel production by direct transesterification of Rhodotorula glutinis biomass. Energies 2018, 11, 1036. [CrossRef]

38. Chen, K.S.; Lin, Y.C.; Hsu, K.H.; Wang, H.K. Improving biodiesel yields from waste cooking oil by using sodium methoxide and a microwave heating system. Fuel 2012, 38, 151-156. [CrossRef]

39. Al-Zaini, E.O.; Olsen, J.; Nguyen, T.H.; Adesina, A. Transesterification of waste cooking oil in presence of crushed seashell as a support for solid heterogeneous catalyst. SAE Int. J. Fuels Lubr. 2011, 4, 139-157. [CrossRef]

40. Kouzu, M.; Kasuno, T.; Tajika, M.; Yamanaka, S.; Hidaka, J. Active phase of calcium oxide used as solid base catalyst for transesterification of soybean oil with refluxing ethanol. Appl. Catal. A 2008, 334, 357-365. [CrossRef]

41. Gryglewicz, S. Alkaline-earth metal compounds as alcoholysis catalysts for ester oils synthesis. Appl. Catal. A 2000, 192, 23-28. [CrossRef]

42. Maneerung, T.; Kawi, S.; Dai, Y.; Wang, C.H. Sustainable biodiesel production via transesterification of waste cooking oil by using $\mathrm{CaO}$ catalysts prepared from chicken manure. Energy Convers. Manag. 2016, 123, 487-497. [CrossRef]

43. Teo, S.H.; Islam, A.; Yusaf, T.; Taufiq-Yap, Y.H. Transesterification of Nannochloropsis oculata microalga's oil to biodiesel using calcium methoxide catalyst. Energy 2014, 78, 63-71. [CrossRef] 
44. Li, F.J.; Li, H.Q.; Wang, L.G.; Cao, Y. Waste carbide slag as a solid base catalyst for effective synthesis of biodiesel via transesterification of soybean oil with methanol. Fuel Process. Technol. 2015, 131, 421-429. [CrossRef]

45. Birla, A.; Singh, B.; Upadhyay, S.N.; Sharma, Y.C. Kinetic studies of production of biodiesel from waste frying oil using heterogeneous catalysts derived from snail shell. Bioresour. Technol. 2012, 106, 95-100. [CrossRef] [PubMed] 